\title{
Peripheral T-Cell Lymphoma in the Oral Cavity of a Cow
}

\author{
Carolina de Castro Guizelini', Rayane Chitolina Pupin², Claudio Severo Lombardo de Barros², \\ Saulo Petinatti Pavarini ${ }^{3}$ \& Danilo Carloto Gomes ${ }^{2}$
}

\begin{abstract}
Background: Squamous cell carcinomas and lymphomas are the most prevalent neoplasms in cattle, the latter usually being attributed to infection by bovine leukemia virus (BLV). Neoplasms of the oral cavity are sporadic in cattle, with but a single case of lymphoma involving this anatomic site in a bovine reported to date. This paper reports a case of lymphoma involving the oral cavity of a dairy cow. The clinical and pathological aspects of the tumor are described and discussed. Case: A 39-month-old Holstein-Friesian cow was presented with weight loss and a tumorous growth in the left masseter region, tearing in the left eye, and mild ipsilateral exophthalmos. Treatment with antibiotics was unsuccessful. The tumor growth was $16 \times 11 \mathrm{~cm}$, with a soft center and firm periphery, multilobulated, with white intercalated with black and friable areas from which a fetid odor emanated. The cut surface was predominantly white-yellow. A cross-section of the head, caudal to the second molar, revealed a mass infiltrating and almost completely obliterating the left nasal cavity, destroying the frontal sinus, the ventral conchae, and the middle and ventral meatus, and compressing the common meatus. The tracheobronchial, mediastinal, and internal iliac lymph nodes were enlarged and masses with similar characteristics to those in the oral cavity replace their parenchyma. Microscopically, the mass consisted of large neoplastic lymphocytes arranged in a non-encapsulated and infiltrative mantle and supported by scarce fibrovascular tissue. The cytoplasm of neoplastic cells was scarce and had distinct boundaries; the nuclei were round or oval, the chromatin was finely granulated, and the prominent nucleolus had occasionally multiplied. Nuclear pleomorphism was marked and there were, on average, five mitotic figures per microscopic field of 400x. Similar neoplastic cells obliterated the normal structure of the tracheobronchial, mediastinal, and internal iliac lymph nodes. In the immunohistochemical examination, labeling was diffuse and moderate in the cytoplasm of neoplastic cells when a CD3 antibody was used, and negative when antibodies to CD79, cytokeratin, and vimentin were used. Due to its characteristic markings in the immunohistochemistry panel, the neoplasm was classified as an unspecified peripheral T-cell lymphoma.

Discussion: The diagnosis of lymphoma was based on clinical signs and gross and histopathological findings, and was confirmed by immunohistochemistry. Lymphomas in cattle are common in several organs as part of enzootic bovine leukosis, a virus-induced type of B-cell lymphoma. However, lymphomas are rare in the oral cavity. The clinical presentation observed in this case points to the upper alimentary tract as the primary site of the neoplasm once clinical respiratory signs were not observed in the cow. The neoplasm cells described here presented a T-cell profile in immunohistochemistry panel, suggesting that the tumor should be included in the sporadic form of bovine leukosis since B-cells are the cellular population in cases of enzootic bovine leukosis. However, since the diagnosis of enzootic leukosis was not definitively excluded in this case, the cause of the neoplasia cannot be conclusively determined. It is concluded that, although rare, lymphomas may indeed occur in the bovine oral cavity and should be included in the differentials list for tumoral growth in the lateral region of the bovine face.
\end{abstract}

Keywords: diseases of cattle, neoplasia, round cells, lymphosarcoma, hematopoietic tumors. 


\section{INTRODUCTION}

Diagnostic surveys carried out in cattle in Brazil indicate that squamous cell carcinomas and lymphomas are the most frequently diagnosed neoplasms in this specie. Lymphomas occur primarily as a result of the infection by bovine leukemia virus (BLV) $[5,10,15-17]$ in a condition known as enzootic bovine leukosis (EBL). The anatomical sites for lymphoma development are varied. EBL most frequent sites include the lymph nodes, abomasum, myocardium, and uterus $[5,13]$. Upper alimentary tract neoplasms in cattle are considered sporadic [11]; among those, squamous cell carcinomas secondary to ingestion of bracken fern are the most frequent [10]. Of less frequent occurrence are cases of gingival hamartoma [19], papilloma [18], osteosarcoma [14] and metastatic melanoma [4]. To date, only one case of lymphoma involving the upper bovine tract has been reported [9]. The objective of this paper is to document a case of multicentric lymphoma with oral cavity involvement in a dairy cow and to address the associated clinical and pathological features.

\section{CASE}

A 39-month-old Holstein-Friesian cow had a history of weight loss for over a month. An increase in volume in the left masseter region and ipsilateral exophthalmos were observed. Antibiotic and anti-inflammatory therapy was performed with no avail. The cow had a poor body condition, was apathetic, and had moderate lacrimation and mild exophthalmos to the left eye. The tumorous growth in the left masseter region was a $16 \times 11 \mathrm{~cm}$, soft at the center and firm at the periphery. Due to poor prognosis, the cow was euthanized. At necropsy, the mass was multilobulated, intercalating white and black areas, from which foul odor exhaled. The mass penetrated the oral cavity in the region of the soft palate and partially enclosed the last two left molars, extending to the gingiva. (Figure 1A). A transverse section of the head at the level of the second molar showed that the mass infiltrated and occupied almost totally the left nasal cavity (Figure 1B), destroying the frontal sinus, the ventral conchae,

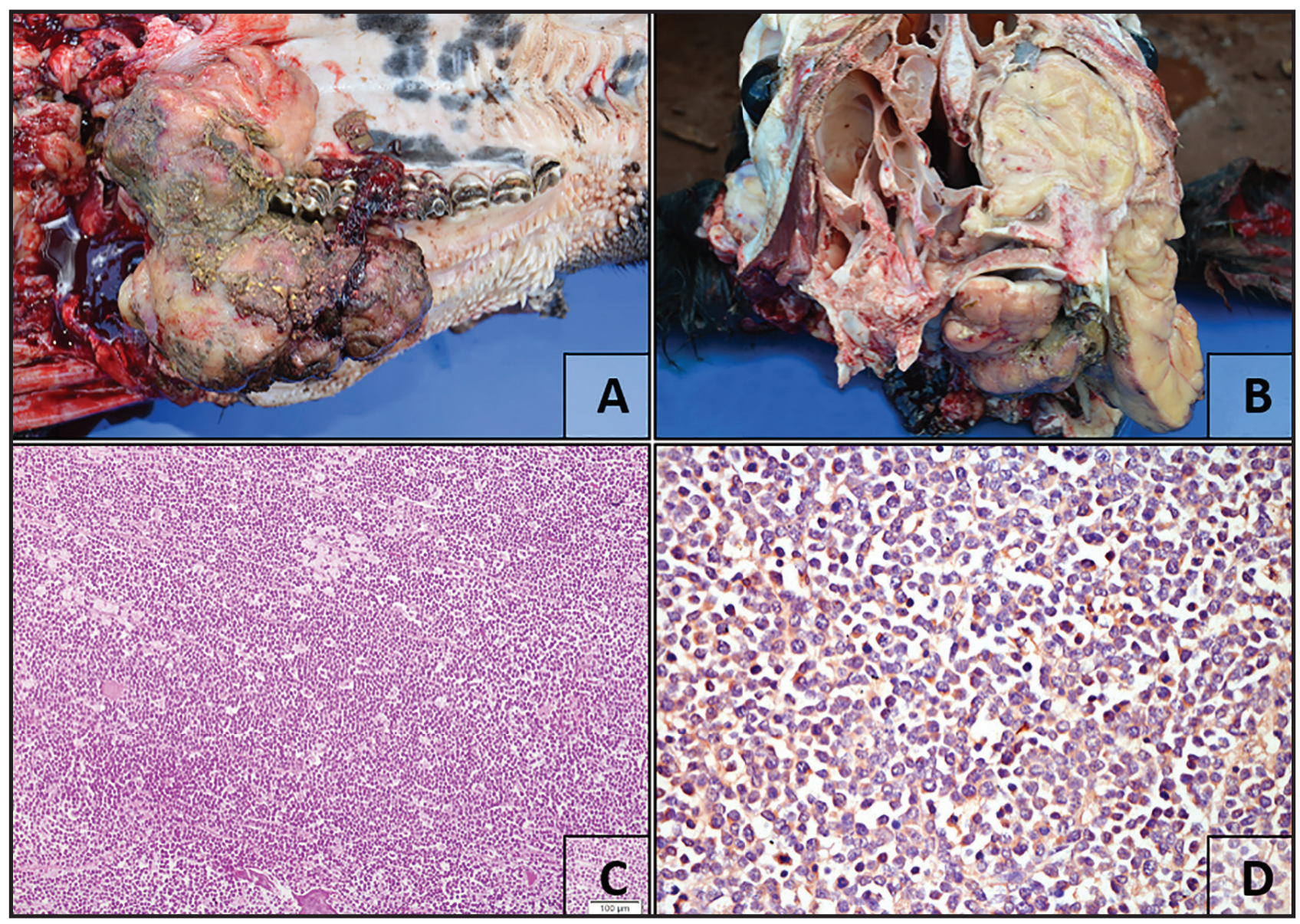

Figure 1. Peripheral T cell lymphoma in the oral cavity of a cow. A- The neoplasm occupies the oral cavity, involving the last molars and the soft palate. B-Aspect of the mass occupying the left nasal cavity and the oral cavity. C- Tumor at the oral cavity consisting of pleomorphic cells without compromise of oral mucosa [H\&E; obj.40x]. D- The cytoplasm of neoplastic lymphocytes marked by the monoclonal CD3 antibody [IHC stain; obj.40x]. 
and the middle and ventral meatus, compressing the common meatus. The cut surface was predominantly whitish-yellow. In addition, the mass extended and compressed the left ocular region, which had a moderate amount of yellowish-green and viscous material on its wall. The internal tracheobronchial, mediastinal, and iliac lymph nodes were enlarged and had normal parenchyma obliterated by soft, white-yellow, homogenous masses of varying sizes. Fragments of several organs were sampled and stored in $10 \%$ formalin solution for subsequent routine stain. Fragments of the tumor were stained for immunohistochemistry using CD $3^{1}$, $\mathrm{CD}_{79} \alpha^{2}$, pan-cytokeratin ${ }^{3}$ and vimentin ${ }^{1}$ antibodies. Microscopically, the mass consisted of round neoplastic lymphocytes arranged as a non-encapsulated, non-delimited and infiltrative mantle, supported by scarce fibrovascular stroma. The neoplastic cells were large, had scarce eosinophilic cytoplasm, distinct boundaries, round to oval nuclei, finely granular chromatin, and prominent, sometimes multiple, nucleoli (Figure 1C). Nuclear pleomorphism was marked, and there were, on average, five mitotic figures per microscopic field of 400x. Similar neoplastic cells obliterate the architecture of internal tracheobronchial, mediastinal, and iliac lymph nodes. In the immunohistochemical examination, labeling was diffuse and moderate in the cytoplasm of neoplastic cells using a CD3 antibody (Figure 1D), and negative using CD79, cytokeratin and vimentin antibodies. Accordingly, the neoplasm was classified as peripheral T-cell lymphoma, unspecified of the oral cavity.

\section{DISCUSSION}

The diagnosis of lymphoma was based on clinical signs, gross findings and was confirmed by histopathology and immunohistochemistry. Lymphomas in cattle are common in several organs, such as lymph nodes, heart, abomasum, uterus, vertebral canal, kidneys, and retrobulbar region $[3,15,20]$, but are rare in the oral cavity [9]. In lymphoma surveys in cattle in several regions of Brazil [3,5,10,13,16,17], there was no involvement of this site in any of the individual studied.

In other reports, bovine with primary lymphoma of the nasal cavity, in addition to weight loss and anorexia, presented signs related to the nasal cavity, such as epistaxis, rales and seromucous nasal discharge $[2,6]$. The clinical presentation observed in this case points to the oral cavity as the primary. Neurological signs, such as head pressing, has been described in bovine lymphoma due to nasal cavity tumors invading the brain [6] or arising there [7]. No neurological sign was observed in the cow of this report. The gross and microscopic of representative sections of the neoplasm revealed a growth similar to other bovine lymphomas $[2,6,13]$. In the canine species, the prevalence of oral cavity lymphomas is greater, and includes the epitheliotropic type as the more common presentation $[1,20]$. However, in the tumor affecting the cow of this report, no neoplastic cells were visualized in the mucosal epithelial lining of the oral cavity justifying the classification of the tumor as non-epitheliotropic lymphoma.

Although no additional tests were performed for the detection of BLV, it is suggested that this animal had the atypical sporadic form of leukosis, since in the enzootic leukosis, B-cells forms the neoplastic cell population [20] and the immunohistochemistry performed in representative samples of the tumor of this report revealed that T-cells predominate among the neoplastic bulk of cells. A similar conclusion was attained by a previous report [2] when the sporadic form was diagnosed after excluding the possibility of BLV infection and identification of T-cells in the tumor, which was restricted to the nasal cavity.

The sporadic form is a condition of unknown etiology that is classically divided into three forms: juvenile, thymic and cutaneous [12,20]. A multicentric lymphoma affecting cattle older than 24 months and consisting of T-lymphocytes has been described [8].

Since the diagnosis of enzootic leukosis could not be ruled out in the case of this report made, it is not possible to speculate on the cause of the neoplasm. It is concluded that, although rare, lymphomas of the oral cavity in cattle should be included in the differential diagnoses list when observing tumoral growth in the lateral region of the cattle face.

\section{MANUFACTURERS}

${ }^{1}$ Dako. Carpinteria, CA, USA.

${ }^{2}$ Biocare Medical. Concord, CA, USA.

${ }^{3}$ Invitrogen. Carlsbad, CA, USA.

Acknowledgments. This study was partially funded by the Coordenação de Aperfeiçoamento de Pessoal de Nível Superior - Brasil (CAPES) - Finance Code 001.

Declaration of interest. The authors report no conflicts of interest. The authors alone are responsible for the content and writing of the paper. 


\section{REFERENCES}

1 Berlato D., Schrempp D., Van Den Steen N. \& Murphy S. 2011. Radiotherapy in the management of localized mucocutaneous oral lymphoma in dogs: 14 cases. Veterinary and Comparative Oncology. 10(1): 16-23.

2 Braun U., Brammertz C., Maischberger E., Bass D.A., Klausmann S. \& Sydler T. 2015. T-cell lymphoma in the nasal cavity of a Brown Swiss heifer. Acta Veterinaria Scandinavica. 57(8): 1-5.

3 Boabaid F.M. 2011. Achados clínicos e patológicos da leucose bovina enzoótica. 72f. Porto Alegre, RS. Dissertação (Mestrado em Ciências Veterinárias) - Programa de Pós-graduação em Ciências Veterinárias, Universidade Federal do Rio Grande do Sul.

4 Brito M.F., França T.N., Jabour F.F., Seixas J.N., Andrade G.B., Oliveira L.I. \& Peixoto P.V. 2009. Metastasizing oral melanoma in a cow. Ciência Rural. 39(4): 1248-1252.

5 Carvalho F.K.L., Dantas A.F.M., Riet-Correa F., Andrade R.L.F.S., Nóbrega Neto P.I., Miranda Neto E.G., Simões S.V.D. \& Azevedo S.S. 2014. Estudo retrospectivo das neoplasias em ruminantes e equídeos no semiárido do Nordeste Brasileiro. Pesquisa Veterinária Brasileira. 34(3): 211-216.

6 Crocker C.B. \& Rings M. 1998. Lymphosarcoma of the frontal sinus and nasal passage in a cow. Journal of the American Veterinary Medical Association. 213(10): 1472-1474.

7 Fighera R.A. \& Barros C.S.L. 2004. Linfossarcoma intracerebral em bovino. Ciência Rural. 34(3): 943-945.

8 Grunberg W. \& Eisenberg S.W.F. 2013. Atypical form of sporadic bovine leukosis (SBL) in the Netherlands. Veterinary Record. 173(16): 398.

9 Lardé H., Nichols S., Babkine M. \& Chénier S. 2014. Laryngeal obstruction caused by lymphoma in an adult dairy cow. The Canadian Veterinary Journal. 55(2): 163-140.

10 Lucena R.B., Rissi D.R., Kommers G.D., Pierezan F., Oliveira-Filho J.C., Macêdo J.T.S.A., Flores M.M. \& Barros C.S.L. 2011. A retrospective study of 586 tumours in Brazilian cattle. Journal of Comparative Pathology. 145(1): 20-24.

11 Munday J.S., Löhr C.V. \& Kiupel M. 2017. Tumors of the alimentary tract. In: Meuten D.J. (Ed). Tumors in Domestic Animals. 5th edn. Ames: John Wiley \& Sons, pp.499-601.

12 Nishimori A., Konnai S., Okagawa T., Maekawa N., Goto S., Ikebuchi R., Nakahara A., Chiba Y. Ikeda M., Murata S. \& Ohashi K. 2017. Identification of an atypical enzootic bovine leukosis in Japan by using a novel classification of bovine leukemia based on immunophenotypic analysis. Clinical and Vaccine Immunology. 24(9): 1-14.

13 Panziera W., Bianchi R.M., Galiza G.J.N., Pereira P.R., Mazaro R.D., Barros C.S.L., Kommers G.D., Irigoyen L.F. \& Fighera R.A. 2014. Aspectos epidemiológicos, clínicos e anatomopatológicos do linfoma em bovinos: 128 casos (1965-2013). Pesquisa Veterinária Brasileira. 34(9): 856-864.

14 Prins D.G.J., Wittek T. \& Barrett D.C. 2012. Maxillary osteosarcoma in a beef suckler cow. Irish Veterinary Journal. 65(15): 1-4.

15 Ramos A.T., Souza A.B., Norte D.M., Ferreira J.L.M. \& Fernandes C.G. 2008. Tumores em animais de produção: aspectos comparativos. Ciência Rural. 38(1): 148-154.

16 Reis M.O., Slaviero M., Lorenzett M.P., Cruz R.A.S., Guimarães L.L.B., Pavarini S.P., Driemeier D. \& Sonne L. 2017. Neoplasmas de bovinos diagnosticados no Setor de Patologia Veterinária da UFRGS, Porto Alegre (2005-2014). Pesquisa Veterinária Brasileira. 37(2): 105-109.

17 Tessele B. \& Barros C.S.L. 2016. Tumores em bovinos encontrados em abatedouros frigoríficos. Pesquisa Veterinária Brasileira. 36(3): 145-160.

18 Tsirimonaki E., O’Neil B.W.O., Williams R. \& Campo M.S. 2003. Extensive papillomatosis of the bovine upper gastrointestinal tract. Journal of Comparative Pathology. 129(2-3): 93-99.

19 Tsuka T., Morita T., Tanaka H., Kono S., Murahata Y., Azuma K., Osaki T., Ito N., Okamoto Y. \& Imagawa T. 2016. Nasal tissue-derived hamartoma in the maxillary gingiva of a calf. Veterinary Research. 12(19): 1-4.

20 Valli V.E., Bienzle D. \& Meuten D.J. 2017. Tumors of the hemolymphatic system. In: Meuten D.J. (Ed). Tumors in Domestic Animals. 5th edn. Ames: John Wiley \& Sons, pp.203-321. 